\title{
Retinoblastoma Clinical Primary Tumor TNM Finding v8
}

National Cancer Institute

\section{Source}

National Cancer Institute. Retinoblastoma Clinical Primary Tumor TNM Finding v8. NCI

Thesaurus. Code C140682.

A clinical finding about one or more characteristics of retinoblastoma, following the rules of the TNM AJCC V8 classification system as they pertain to staging of the primary tumor. Each eye is scored for CT criteria, and the CT category for the patient is based on the most advanced eye. (from AJCC 8th Ed.) 